DOI: https://doi.org/10.31992/0869-3617-2019-28-144-154

\title{
Area Studies at the Modern University: Experience in Studying International Communication Strategies
}

Olga A. Nesterova - Dr. Sci. (Philosophy), Prof., e-mail: onesterova@hse.ru

olga L.Solodkova - Cand. Sci. (History), Assoc. Prof., e-mail: Osolodkova@hse.ru

National Research University Higher School of Economics, Moscow, Russia

Address: 20, Myasnitskaya str., Moscow, 101000, Russian Federation

Abstract. In this paper, we show the importance of including the large corpus of scholarly, popular and media texts describing the experience of $20^{\text {th }}$-century Russian and Soviet Indologists in bachelor's Asian studies programmes. We explain the significance of the practical work of Soviet Asian scholars on developing and implementing international communication strategies and practices and show that this work is topical and relevant for modern tertiary education. We emphasize the extensive experience accumulated by Russian Indologists in developing scenarios and models of interaction between Russia and Asian countries that take regional particularities into account. We examine the work of the Russian Indologist, scholar, journalist, publicist and professor Leonid Mitrokhin (1934-2002), winner of the Nehru Award (1985), who worked for over a decade in India and devoted his entire life to studying South and Central Asia. We analyse Leonid Mitrokhin's key communicative practices, whose results are reflected in his monographs, popular books and articles. The results of our linguocultural study confirm the effectiveness of the implementation of friendly communication strategies in Indo-Soviet relations in the 1960s and 1970s. The case study of Leonid Mitrokhin's work shows the broad range of professional competencies of Soviet Indologists, who had in-depth knowledge of the political and sociocultural makeup of South Asia, the systemic connections between individual social, economic and political groups and institutes, and the ethnopsychological, ethnocultural and religious particularities of interethnic communication. The knowledge and skills of Soviet Indologists allowed them to make accurate forecasts of the development of the political and economic situation in South Asia and neighbouring regions, promote communication, make expert assessments in key areas of interaction between the USSR and countries in the region, elaborate effective communication strategies, and shape a positive image of their country in the international arena. The study of the communication experience of Soviet Indologists shall help contemporary students to learn the methodology of area studies, develop their strategic thinking, expand their study and research interests, improve their knowledge of the region's history and interregional relations, and learn the basics of foreign impact strategies and the practice of foreign propaganda in Asia.

Keywords: international area studies, communication strategies, Indo-Russian relations, Leonid Mitrokhin, South Asia

Cite as: Nesterova, O.A., Solodkova, O.L. (2019). Area Studies at the Modern University: Experience in Studying International Communication Strategies. Vysshee obrazovanie v Rossii = Higher Education in Russia. Vol. 28, no. 11, pp. 144-154.

DOI: https://doi.org/10.31992/0869-3617-2019-28-144-154

\section{Introduction}

The current development of economic and political relations between Russia and Asian countries makes it important to train qualified specialists with a good knowledge of Asian languages and a broad range of competencies that

(cC) BY 4.0 
allow them to apply their linguistic knowledge and speaking to analytic, communicative and practical activities in different sectors of economic, political and sociocultural communication in contemporary Eurasia. The challenges faced by Russia on the Eurasian continent call for the development of new conceptual approaches to teaching bachelor's and master's students and require strengthening interdisciplinary ties, refreshing the content of courses, and searching for new forms of teaching and independent student work. Students majoring in Asian studies must acquire in-depth knowledge of individual countries as well as mastering research methodology and the notions and categories of contemporary area studies. Tertiary study programmes in the field 41.03.01 "International Area Studies" have become increasingly popular in recent years and are currently offered at the best Russian universities (Moscow State University, Higher School of Economics (HSE), Moscow State Institute of International Relations (MGIMO University), Russian Presidential Academy of National Economy and Public Administration (RANEPA), Peoples' Friendship University of Russia, etc.).

\section{International Communication Strategies in Contemporary Academic Programmes for Area Studies Majors}

The discipline "International Area Studies" at MGIMO University is a unified interdisciplinary subject field with a broad theoretical and methodological framework and a practice-oriented approach. It has its own textbooks that describe the laws of regionalization, trends in the transformation of the world's regions ${ }^{1}$, and different aspects of the development of global regions and regional subsystems in international relations. ${ }^{2}$ MGIMO adopts an axiological ap-

\footnotetext{
${ }^{1}$ See, for example, Voskresensky, A.D. (Ed). Mirovoye kompleksnoye regionovedeniye: Vvedeniye $v$ spetsialnost': Uchebnik [International Comprehensive Area Studies: Introduction to the Field. Textbook]. Moscow, 2019. Available at: http://znanium. $\mathrm{com} /$ catalog/product/1005678

${ }^{2}$ See, for example, Baykov, A.D., Belokrenitsky, V.Y., and Yermolayev, A.O. (Eds). Praktika
}

proach in order to show that "education is a public, social and individual value" [1, p. 174].

The Peoples' Friendship University of Russia is one of the oldest Russian universities catering to international students. Its Faculty of the Humanities and Social Sciences offers a master's programme in International Area Studies that includes several different majors (Middle East; China; Russia and neighbouring regions; Francophone countries) ${ }^{3}$.

Today, HSE has the only Russian double degree programme in area studies: "Economics and Politics in Asia" (academic supervisor: D. Shcherbakov). Its graduates receive a bachelor's degree from HSE and a Bachelor of International Studies (Chinese/Korean/Japanese Studies) from Kyung Hee University in Korea ${ }^{4}$.

The HSE Faculty of World Economy and International Affairs (dean: S. Karaganov) has opened the Department of International Regional Studies (director: V. Vishnyakova) with six research and education sections that study area studies problems and develop new study programmes. Three of these sections specialize in the study of different aspects of Asian regions: Middle Eastern and North African Studies (director: A. Baklanov), Linguistic and Cultural Studies (O. Nesterova), and South and Southeast Asian Studies (O. Solodkova). This department aims to cast bridges between area studies as an interdisciplinary field of theoretical and applied research and the content of tertiary area study programmes.

The contemporary Eurasian communication space has a complex multilevel structure

zarubezhnogo regionovedeniya $i$ mirovoy politiki: Uchebnik [Practice of International Area Studies and International Policy. Textbook]. Moscow, 2016. Available at: http://znanium.com/catalog/product/515456

${ }^{3}$ International Area Studies, Official website of the Peoples' Friendship University of Russia. Available at: http://admission.rudn.ru/ma_region

${ }^{4}$ For more details about the content of the study programme and the study formats, see "Bachelor's Programme 'HSE and Kyung Hee University Double Degree Programme in Economics and Politics in Asia". Available at: https://www.hse.ru/en/ba/epa/ 
shaped by the impact of different geopolitical, economic, ethnocultural, ethnogeographic and historical factors. The knowledge of the main rules and particularities of regional communication practices and strategies is a key professional competency for area studies specialists. The linguocultural study of Asia, covered in different disciplines of area studies programmes (not only linguocultural courses but also courses and seminars on economics, politics, international relations, sociology, ethnopsychology, and cultural anthropology), includes language learning and the study of historical, geographic, natural, climatic, political and social phenomena, ethnic and cultural particularities, and concepts represented in linguistic worldviews as well as the acquisition of methods of effective interaction with representatives of the studied languages and cultures and regional communities. In contrast to classical Asian studies, which tend to examine ancient and modern texts written in Asian languages and, as a rule, confine themselves to individual countries or small groups of countries with common or similar languages and cultures (the well-known Russian Asian scholar Vasily Alekseyev stressed that studying Asian countries "without Asian texts has nothing to do with Asian studies" and that "Asian studies are a complex field or, more precisely, a complex of different fields studying Asian countries" [2, p. 191]), contemporary area studies break out of the narrow academic approach and use many different languages (Asian as well as European) as their tools. This approach stems, first and foremost, from the particularities of regional structures and their interactions, which are usually not limited to a single culture or a single type of linguistic communication strategy but are integrated into a multicultural and multilinguistic communication space. Asian studies were initially a unified field in Russia. However, as far back as the 1960s, the Russian Asian scholar N. Konrad wrote about the emergence of the new trend of specialization in Soviet Asian studies and wrote that this "should be seen as the onset of a new stage of Asian studies; <...> as a sign of the end of Asian studies as we know them" [3, p. 11]. In the $20^{\text {th }}$ century, Russian oriental scholars gained tremendous experience in elaborating strategies, scenarios, and models for Russia's interaction with Asian countries that took regional particularities into account. For them, foreign languages were not only tools of personal and business communication but also means of conducting analytic work, implementing regional impact strategies, and creating and consolidating a positive image of their country (the USSR or the Russian Federation) in the minds of local inhabitants.

The goal of the present article is to show the importance of using scholarly, popular and media publications and archival materials presenting the experience of Soviet Indologists of the $20^{\text {th }}$ century and the work of Soviet South Asian scholars in bachelor's Asian studies programmes.

\section{Examining international communication strategies (case study of the work of the In- dologist Leonid Mitrokhin)}

The study of South Asia from the historical, political, sociocultural, and linguistic and cultural standpoints gets a lot of attention in the coursework of the HSE Department of International Regional Studies, as India (one of Russia's main strategic partners in the region) is currently undergoing a period of intense economic and socio-political growth. As the Indian ambassador to Russia Pankaj Saran noted, new political forces are appearing in the region, democratic institutes are becoming stronger, young people are increasingly participating in political processes, the Indian Federation is becoming more consolidated, regional parties are developing, and the coordinating and integrating role of the central government is growing. $\mathrm{At}$ the same time, Indo-Russian ties and diplomatic relations are actively developing. Over the past 70 years, these relations have been marked by a special type of friendly communication aiming at strategic partnership. The development

\footnotetext{
${ }^{5}$ Public lecture of Indian Ambassador Pankaj Saran at HSE. URL: https://www.hse.ru/en/ma/politanaliz/news/203699508.html
} 
of Indo-Russian relations has been based on the ideas and values set forth in the Treaty of Friendship and Cooperation (1993), the Declaration on Strategic Partnership (2000), and the joint statement "Partnership for Global Peace and Stability" adopted at the bilateral summit in Goa (2016). The study of the interaction between Russia and India in the $20^{\text {th }}$ and $21^{\text {st }}$ centuries helps students majoring in area studies to broaden their competencies in the theory and practice of international communication.

The study of the work and communication experience of Soviet Indologists shall help contemporary students to (1) learn the methodology of South Asian studies, (2) acquire and develop the basics of strategic thinking, (3) expand the range of topics of research and applied projects, (4) acquire knowledge about the history of the region and interregional and intraregional relations, (5) become familiar with the causes and consequences of communicative successes and failures in the sphere of interregional interaction, and (6) study the foundations of the implementation of foreign impact strategies and foreign propaganda methods.

The relations between India and the USSR in the 1970s are a noteworthy historical example of international cooperation whose comprehensive in-depth study shall help students majoring in South Asian studies to enrich their competencies in all six aforementioned areas. During this favourable period in the history of the two countries, the communication strategy of friendship was successfully implemented in a bilateral and multidimensional manner. At that time, Indian scholars noted that the friendship between India and the USSR was "a striking example of how two peoples and systems with different political ideologies and socio-economic structures can work together in close harmony for mutual benefit, and progress" [4, p. 1]. Soviet scholars said that these relations developed successfully "both in the conditions of international peace and during periods of tension on the subcontinent" and were marked by "identical or close stances on key international issues" [5], always advocating the cause of peace.
Russian and Indian scholars have proposed different explanations for the unique phenomenon of Indo-Soviet friendship, considering it to be the result of political strategies of international cooperation [6], pointing to similarities in the historical and cultural development of the two countries, studying the tools and technologies of effective foreign propaganda [7], and emphasizing the friendly nature of these relations that arose and developed in the intercultural and foreign policy domains. The formation of the image of the friend was a unique phenomenon in $20^{\text {th }}$-century international relations. The concept of friendship not only figured in official documents and public texts but also became part of intercultural communication in the personal, official and business spheres. Indo-Soviet relations were considered to be based on trust, partnership and positive thinking, while the concept of friendship and the image of the friend were widely used both by journalists and by researchers and analysts [8; 9].

Area studies majors should know that the experience of Indo-Soviet cooperation and the mechanisms of creating a mutually positive image in international relations in the $1970 \mathrm{~s}$ is a topical research problem today for specialists on foreign propaganda [7] studying the technologies for "shaping the foreign image of the USSR using a system of concrete, systematically applied methods and techniques capable of impacting public opinion" [7, p. 4]. The successful implementation of the foreign propaganda strategy in the second half of the $20^{\text {th }}$ century led to a systematically developed image of the friend and concept of friendship that were fairly common in different spheres of interaction from economics and politics to culture and education. Soviet scholars noted that the cooperation between India and the USSR "turned into the friendship of great peoples" [5], as shown by the results of polls: after $1971,85 \%$ of Indian respondents had a favourable attitude towards the USSR in comparison to only $2 \%$ towards the USA [5]. In his description of Indo-Russian friendly ties, Russian scholar S. Lounev notes, "At the same time it is necessary to point out the relative closeness of the two countries in the 


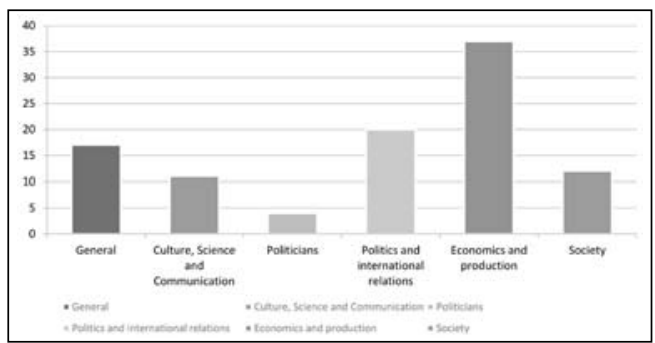

Fig. 1. Subject Areas of English-Language

Publications on Indo-Soviet Relations over the Period 1947-1977

sphere of cultural life (the enormous differences of Russian and Indian civilisations notwithstanding): spiritualism as an immanent element of both cultures opposes the materialism and consumerism of the developed world, while the multinational and multiconfessional composition of both countries brings them closer" [10].

In the framework of a joint research project between the sections of Linguocultural Studies and South Asian Studies, we conducted a linguocultural analysis of the concept of friendship, ${ }^{6}$ as it was shaped in the public awareness of Indian target audiences. Analysing the subject matter and content of English-language publications from 1947 to 1977 on different aspects of Indo-Soviet relations (a total of 1,166 books and articles published by over a hundred Indian and foreign journals and publishing houses) listed in the bibliography compiled by the Indian scholar Attar Chand [4], we examined the rate of occurrence of the concept of friendship in media and scholarly works of the time and identified the semantic ties of this concept with other semantic dominants of the communication space. Attar Chand arranged the publications in 46 subject section. The subject groups with the biggest number of publications are (1) General (203 publications, 17\% of the total number of texts), (2) Culture, science and communication (128 publications, $11 \%$ ), (3) Politicians (49 publications, 4\%), (4) Politics

${ }^{6}$ The results of a comparative linguocultural study of the concept of friendship as a key word in English and Russian-language literature are presented in Anna Wierzbicka's book [11, pp. 63-120].

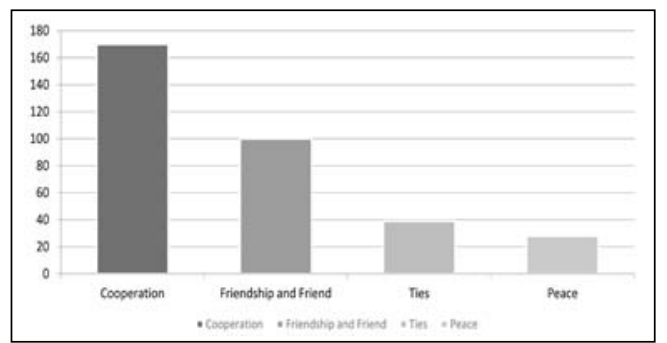

Fig. 2. Percent Occurrence of the Words "Cooperation", "Friendship" and "Friend(s)", "Ties" and "Peace" in Text Titles

and international relations (229 publications, $20 \%),(5)$ Economics and production (426 publications, 37\%), and (6) Society (123 publications, $12 \%$ ). This classification gives a fairly good idea of the priorities of the two countries in South Asia and the global arena. Economic cooperation and international relations served as the foundations of Indo-Soviet communication. Together, "Economics and production" and "Politics and international relations" account for over half of the total number of newspaper and journal publications (Fig. 1).

An analysis of the contents of texts published during this period shows that the titles of books and journal and newspaper articles often included the words "Cooperation", "Friendship", "Ties", "Peace", and "Friend(s)", which served as key elements of political and intercultural discourse. In book and article titles, the word "Cooperation" occurs 170 times $(14.6 \%$ of all titles), "Friendship" 82 times ( $7 \%$ ), "Ties" 39 times $(3.3 \%)$, "Peace" 28 times $(2.4 \%)$, and "Friend(s)" 18 times (1.5\%). Thus $28.8 \%$ (almost a third) of all titles of materials published in India on Soviet-Indian relations during the period in question contain direct verbal references to the importance and widespread occurrence of the concept of friendship and the image of the friend (Fig. 2).

In Indo-Soviet communication, the concept of friendship was closely tied to the concept of peace, and its content reflected different types of close ties (cooperation, mutual support). Friendship was understood as a key condition for the interaction of the two countries in the 
struggle for peace, and Indian authors noted that "one of the major factors for India's friendship with the Soviet Union is the common struggle of these two countries against imperialism and for world peace" [12, p. 39].

The economic cooperation between India and the USSR was an important axis around which other types of relations developed in the region. While developing this partnership, the Soviet Union conducted a carefully planned long-term propaganda campaign with the help of specialists that had a good knowledge of regional problems, history, culture, ethnopsychology, and traditions and were able to implement effective personal, official, business, and media propaganda communication strategies.

An example of the combination of practical, scholarly and educational activities in Asian regional studies is the work of the Indologist Leonid Mitrokbin (1934-2002), winner of the Nehru Award and author of 14 monographs, 62 articles, over 100 media materials, and about 1,000 pages of correspondence with Indian friends and colleagues. One of the key participants in the process of creating the image of a friend in Soviet-Indian relations, Mitrokhin used different types of interaction in his research and journalist activities: personal ties, official relations and media propaganda. Embarking upon two longterm missions to India (lasting 11 years in all), Leonid Mitrokhin worked from June 1964 to October 1969 in Madras and Delhi as senior editor and deputy director of the Novosti Press Agency (APN) office. From 1974 to 1979, he served as an adviser on counterpropaganda to the Soviet Embassy in India and deputy director of the APN Information Centre in Delhi.

Leonid Mitrokhin was editor-in-chief of the magazine Soviet Land and also oversaw the publication of books and pamphlets on Soviet sociocultural development and Indo-Soviet intercultural communication. The magazine appeared twice monthly and was similar in size to the authoritative Soviet weekly Ogoniok. Prakash Chandra, an Indian specialist on propaganda wars between the USA and the USSR, notes that "more than half a million copies of The Soviet
Land printed in 13 languages were distributed throughout India in 1979. In comparison, the American magazine Span has less than one-third of the Russian circulation". . Culture and intercultural communication were vital areas of activity. The word "friend", which was often used by Leonid Mitrokhin in his publications ("Friends of the Soviet Union", "Lenin: A Friend of the Eastern Peoples") [13; 14], played a key role in communication strategies. However, "friend" was more than just a word in Indo-Soviet relations. The Soviet Embassy in India actively promoted the establishment of Indo-Soviet friendship societies. Prakash Chandra writes that the Russians' words about friendship were consistent with their deeds: "The Russians < .. > have assisted in the formation of Indo-Soviet friendship societies that have more than 200,000 members" ${ }^{8}$.

The work of the Indologist Leonid Mitrokhin can help students majoring in area studies to get acquainted with the use of soft power communication strategies in journalism and editing as well as in personal relations. The rich cultural heritage of the peoples of the USSR and India along with multidimensional intercultural dialogue served as foundations for implementing such strategies in international relations. As India and the Soviet Union were multi-ethnic states, Soviet Land accorded a lot of attention to the preservation and development of ethnic cultures. A series of articles by Leonid Mitrokhin was devoted to such subjects as the everyday life of Soviet collective farm workers in Tajikistan and mixed marriages and Hindi language study programmes in this republic, the work of the Soviet-Indian Association for Cultural Ties, etc. Comparisons between the life of ordinary Soviet and Indian people and the attention to the common man and his needs inevitably met with the sympathy of Indians, and even such ideological opponents as Prakash Chandra were forced to admit that «one senior editor of a local language

${ }^{7}$ Chandra, P. Soviets wage vigorous propaganda war in India. The Christian Science Monitor New Delbi. Available at: https://www.csmonitor. com/1982/0118/011833.html

${ }^{8} \mathrm{Ibid}$. 
newspaper in Punjab, with a great deal of political influence, told the Sunday Magazine: 'I feel much more comfortable with the Russians. They are just like us'».'

As the implementation of the policy of "soft power" gave a lot of importance to intellectual elites interacting in the domain of culture, discussing topical themes, and showing a common understanding of political and cultural processes, Leonid Mitrokhin published the correspondence between Nicholas Roerich and Rabindranath Tagore in Soviet Land [15, pp. 29-31], showing the common views of these world-famous cultural figures on the threat of fascism and the preservation of peace in the years preceding World War II.

Another effective instrument of the USSR for implementing soft power strategies was fiction, which was specially translated into Bengali, Hindi, Urdu, Telugu, Malayalam, Kannada, Punjabi and Tamil. The target audience was often children and teenagers. The high degree of impact of soft power (Russian and Soviet children's literature) on the individual and collective awareness of Indians is confirmed by the recollections of eyewitnesses: "Russian children's literature is believed to have blurred the lines between propaganda and art, perhaps like no other children's literature. I don't remember any disreputable titles that glorified electrification and agriculture. I read numerous folk tales and children's books printed by Moscow publishers - Raduga and Progress. <...> The Russians came to India and distributed their stories virtually for free. If this was propaganda, no one has bad memories of imbibing it. My favorite part of the evening, after having shopped for twenty hard-bound books for ten rupees at the Soviet Book Exhibition, was to go to Hotstuff, the only American-style joint in town. I would leaf through the illustrations by Igor Yershov, listen to Wham, drink a strawberry shake and eat a Big Boy burger". 10

\footnotetext{
${ }^{9}$ Ibid.

${ }^{10}$ Palash Krishna Mehrotra. Baba Yagaonthe Ganges. Available at: https://www.nytimes.com/2017/10/14/ opinion/india-soviet-union-books.html
}

The effectiveness of the methods used by the USSR to promote Soviet culture in the 1970s and 1980s, which can be described as linguistic and linguocultural strategies, has been described by the prominent contemporary Indian poet Subodh Sarkar: "When I was a student, Russian literature was second only to Bengali literature for us! <..> We did more than simply read Russian writers in Bengali: we got acquainted with culture, ethnography, military history, and migrations". ${ }^{11}$

In the linguocultural topics taught to area studies majors in such courses as political science, the theory of international relations, and the theory of intercultural communication, one of the most important subjects is strategies for shaping the cultural space with the help of educational technologies (including the mass teaching of foreign languages to local inhabitants). For example, in 1974-1976, Russian became the most popular foreign language studied in India. Many scholars and journalists spoke about the growing interest in it. ${ }^{12}$ "After English, Russian is now the most popular foreign language in India. There are more than 50 universities and institutes in India offering various types of courses in the Russian language. Besides this, about 50 branches of the Indo-Soviet Cultural Society, spread all over the country, have been organizing evening classes for the study of the Russian language." 13

Strategies of cultural influence in the domain of education are highly effective. Leonid

${ }^{11}$ Danilkin, L. (2018). Nasledstvo iz Kal'kutty. Rossiya uchastvuyet $\mathrm{v}$ glavnoy knizhnoy yarmarke Indii [Heritage from Calcutta: Russia Participates in India's Leading Book Fair]. Rossiyskaya gazeta. Stolichny vypusk, no. 31 (7494), Feb 12. Available at: https://rg.ru/2018/02/12/na-knizhnojvystavke-v-indii-delegacii-iz-rf-udelili-osoboevnimanie.html

${ }^{12}$ Cf. Dharm Vir (1975). Growing Interest in Russian Language. Clarity, 29 November, p. 3; Pavanan (1974). Russian Language Classes at Trivandrum. Youth Review, 4 May; Russian Most Popular. National Herald, 14 September, 1976.

${ }^{13}$ Russian - Second Most Popular Foreign Language in India. Sajit, November, 1976, p. 16. 
Mitrokhin and other Asian regional scholars often used these strategies in their work. It was more than just a question of organizing Russian language courses or writing magazine and newspaper articles about the system of linguistic training. The interaction of education systems (especially at the tertiary level) not only trains researchers for mutual study but also promotes the development of communication processes. In the 1970s, the Soviet Union attached a lot of importance to training Indologists and offering Sanskrit courses, emphasizing that, as far back as the $19^{\text {th }}$ century, "the systematic training of Indologists was of great importance for the future development of Russian-Indian cultural contacts. Indologists, most of whom had graduated from Petersburg University, soon came to play a prominent role in establishing and strengthening direct contacts between the scholars of the two countries." 14

After returning from India and resuming his academic work in Moscow, Mitrokhin supervised dissertations not only by Russian Indologists but also by Indian graduate students. Under his supervision, Sudeshna Sarkar, an Indian graduate student from Calcutta, conducted research on the history of Indo-Russian ties and diplomatic relations and successfully defended a candidate of sciences degree with the title "Establishing a Consulate in Bombay: The Problem of the Emergence and Activities of the First Russian Governmental Mission to India, 1858-1906". The existence of theses written and defended by Indian graduate students in Russian points to effective international communication in the sphere of education and to the successful implementation of communicative strategies in the humanities for transmitting the culture of scientific thinking, the framework of notions and categories, and methodology.

In the study of regional communication strategies, it is important to understand why some of them do not lead to the expected results, while

${ }^{14}$ Lusternik, E.Y. (1970). Leningrad University's Contacts with India. Soviet Review, 1 September, pp. 27-39 (p. 38). others are fairly successful. Studying the experience of practical specialists who developed Russian area studies and, in particular, Asian studies in the $20^{\text {th }}$ century, contemporary students can learn to choose optimal communication models by analysing a concrete situation, which may be contradictory or even conflictual, and to interpret and comment facts that may be considered negative in the historical memory of the other nation.

A case in point is an article written by Leonid Mitrokhin for Soviet Land that described the fate of the Indian revolutionaries Virendranath Chattopadhayaya, Abani Mukerji and Ghulam Abdul Khan, who died during the Stalinist repressions. Following the communicative strategy of friendship, the author strives for the openness of honest friendly relations that are based on trust and that exclude lying or passing things over in silence: "I was sure that we had to tell our Indian friends and everyone else the whole truth, for it was part of our common history and our common tragedy" [16, p. 30].

The development of friendly communicative practices was furthered by the study and broad press coverage of problems that were vital for both countries. World War II was a key area of interaction between India and the USSR in the $20^{\text {th }}$ century. In Indian archives, Leonid Mitrokhin found unique documents about volunteers who constructed the railway from India through Baluchistan to Eastern Iran (the socalled "East Persian Route"15) to enable supplementary deliveries of arms, material valuables and food during the war years. These documents served as a basis for a series of articles for the magazines Soviet Land and National Herald describing the priceless selfless assistance of Indians who solidarized with the Soviet people in their struggle against fascism. Mitrokhin's articles, written in English and Russian, subsequently led to his book on the Indian friends of the Soviet Union [13]. In the foreword to the book, General Secretary of the World Peace Council

${ }^{15}$ Thirty thousand men, women and children from 15 Indian ethnic groups built the railway, which was used to delivery hemp, copper, rubber, tin and mercury to Russia. 
Romesh Chandra wrote, "The author, my friend Dr. Mitrokhin, has done a remarkable work in bringing together facts and documents which demonstrate the meaning of Indo-Soviet friendship during the period of the Great Patriotic War of the Soviet people" [13, p. ix].

In the 1970s, the development of the "friendly" communication strategy of the USSR in India was encouraged by the international situation: the start of the détente process in the international arena. The creation of a positive image of the political elites of both countries became important. In India, the peaceful declarations of Soviet leaders were greeted with enthusiasm. In September 1974, Leonid Mitrokhin got a letter from the poet Niaz Hyder ${ }^{16}$ with a traditional poetic greeting in Urdu on the occasion of Leonid Brezhnev's visit to India. During this period, Soviet Land supported the ideas of friendship and peaceful coexistence. The promotion of a positive image of statesmen, national leaders, heroes of the national liberation movement, and fighters against British colonialism was a key goal of propaganda during this period. Soviet Land marked the $100^{\text {th }}$ birthday of Jawaharlal Nehru with a special edition entitled "Remembering $\mathrm{Nehru}^{\prime 17}$ with Leonid Mitrokhin's article "Jawaharlal Nehru, India and the Spanish War"18 about Nehru's trip to Spain in 1938 and his meeting with Dolores Ibárruri. The collective monograph Jawabarlal Nebru: Reminiscences was published in Russian in Moscow and in English in Delhi [17]. It included Mitrokhin's article "Nehru's Contribution to Indo-Soviet Relations". Publications in the Soviet press were supplemented by articles in Indian newspapers on the occasion of special dates.

\section{Conclusions}

While Indologists conducting practical and research work in South Asia in the 1960s and 1970s did not call themselves "regional scholars", they

\footnotetext{
${ }^{16}$ Letter from Niaz Hyder to Mitrokhin L., 18.09.1974. Personal archive of L. Mitrokbin.

17 Soviet Land, 1989, November, no. 11, p. 14.

${ }_{18}$ Mitrokhin, L. (1989). Jawaharlal Nehru, India and the Spanish War. Soviet Land, no. 11, pp. 52-53.
}

were specialists whose competencies went far beyond the Asian studies education they got at the university. Just as Leonid Mitrokhin, whose work we have described in this article, dozens of diplomats, journalists, scholars, professors, and other professionals working in India and developing inter-state and inter-cultural communication had not only a knowledge of the languages, history, geography, culture and religion of the country and region but also a profound understanding of the entire political and socio-cultural structure of the larger region encompassing their country of specialization. These people used their enormous knowledge of area studies for forecasting the development of the political and economic situation in South Asia and neighbouring regions, establishing long-term effective contacts with the representatives of different social groups and institutes, making expert evaluations of key issues of the interaction between the USSR and regional countries, elaborating and introducing effective communication strategies, and, last but not least, creating a positive image of their country in the international arena. The experience of these orientalists is particularly valuable today for training a new generation of regional scholars specializing in South Asia and should be included in study programmes of the discipline 41.01.01 "International Area Studies" as course material, themes for student research and applied projects, and topics for term papers and theses. Although a South Asian regional studies programme has not been offered by HSE so far, scholars at the Department of International Regional Studies are actively conducting research on international communication strategies and interaction practices in this region with the help of linguocultural methods, developing ties with colleagues at Russian and Indian universities and research institutes, working in archives, and teaching different aspects of the history, theory and practice of Indo-Russian relations in the courses of other study programmes.

\section{References}

1. Voevoda, E.V., Belogurov, A.Yu. (2018). Axiology of Education in the Discourse 
of Contemporary Policy. Polis. Political Studies. No. 6, pp. 172-179. DOI: https://doi.org/10.17976/jpps/2018.06.12. (In Russ., abstract in Eng.)

2. Alekseev, V.M. (1982). Nauka o Vostoke. Stat' $i$ i dokumenty [The Science of the East. Articles and Documents]. Moscow: Nauka Publ., 535 p. (In Russ.)

3. Attar Chand (1978). Bibliograpby of IndoSoviet Relations 1947-77. A book of readings with selected abstracts. New Delhi. Sterling Publishers PVT Ltd., 152 p.

4. Konrad, N.I. (1972). Staroe vostokovedenie $i$ ego novye zadachi [Old School Oriental Studies and Its New Tasks]. In: Konrad, N.I. Zapad $i$ Vostok [West and East]. Moscow: Glavnaya redaktsiya vostochnoy literatury Publ., pp. 7-28. (In Russ.)

5. Monin, S.M. (1980). Sovetsko-indiyskie otnosheniya $v$ 70-kh godakb [The Soviet-Indian Relations in the $\left.1970^{\text {th }}\right]$. Voprosy istorii. No. 2, pp. 40-51. Available at: https://dlib.eastview. com/browse/doc/7052489 (In Russ.)

6. Kapur, K.D. (1983). Soviet Strategy in South Asia, New Delhi. 315 p.

7. Silina, L.V. (2011). Vneshnepoliticheskaya propaganda $v$ SSSR $v$ 1945-1985 gg. (po materialam otdela propagandy $i$ agitatsii $T s K V K P(b)-K P S S)$.[Soviet International Propaganda in the USSR in 1945-1985th]. Moscow: Rossiyskaya politicheskaya entsiklopediya Publ., 208 p. (In Russ.)

8. Chatterjee, Basant. (1974). Indo-Soviet Friendship: An Analytical Study, S. Chand \&Co., New Delhi. 259 p.

9. Venugopal, Rao, M., (1976). Friends and Partners: Five Years of Indo-Soviet Treaty. New Delhi, Allied Publishers. 236 p.

10. Lounev, S.I. (2017). Soviet-Indian Relations
(1955-1971): The Birth of a Friendship. MGIMO Review of International Relations. No. 2(53), pp. 24-51.

11. Wierzbicka, A. (2001). Ponimanie kul'tur cherez posredstvo klyuchevykb slov [Understanding Cultures through their Key Words]. Moscow: Yazyki slavyanskoy kul'tury Publ., 288 p. (In Russ.)

12. Bhambbri, C.P. (1984). Perspective on Soviet Contribution to India in Defence Efforts. Indo-Soviet Relations. Problems and Prospects. New Delhi, pp. 38-44.

13. Mitrokbin, L.V. (1977). Friends of the Soviet Union. India's Solidarity with the USSR during the Second World War in 1941-1945. Bombay. 276 p.

14. Mitrokbin, L. (1972). Lenin: A Friend of the Eastern Peoples. Soviet Review, 18 April, pp. 32-34.

15. Mitrokbin, L.V. (1991). Nikolai Roerich and Rabindranath Tagore (history of correspondence). Soviet Land. New Delhi. No. 6, pp. 29-31.

16. Mitrokbin, L.V. (1991). A Triple Trap. Story of Three Comintern Activists in the Years of Stalinist Terror. Soviet Land. New Delhi. No. 4, p. 30-32.

17. Jawaharlal Nehru. Reminiscences. (1989). Eds: E.N. Komarov, L.V. Mitrokhin. New Delhi, Sterling Publishers. 204 p.; Russian Edition: Komarov, E.N., Mitrokhin, L.V. (Eds). (1989). Dzhavakharlal Neru. Vospominaniya $i$ issledovaniya [Memoirs and Research]. Moscow: Nauka Publ., 204 p. (In Russ.)

The paper was submitted 26.06.19

Received after reworking 28.08.19; 30.09.19 Accepted for publication 04.10.19

Регионоведение в современном вузе: опыт изучения международных коммуникативных стратегий

Нестерова Ольга Александровна - А-р филос. наук, проф. E-mail: onesterova@hse.ru

Солодкова Ольга Иеонидовна - канд. истор. наук, доцент. E-mail: Osolodkova@hse.ru, Национальный исследовательский университет «Высшая школа экономики», Москва, Россия Адрес: 101000, г. Москва, ул. Мясницкая, 20 
Аннотация. В статье обосновььвается необходимость включения в структуру современных образовательных программ бакалавров, спеииализирующихся на изучении регионов зарубежной Азии, большого корпуса научных, научно-просветительских и публичистических текстов, в которых аккумулируется опыт отечественных индологов ХX в. Раскриьвается значение деятельности советских востоковедов и регионоведов по разработке и реализачии международных коммуникативных стратегий и практик; выявляется актуальность и востребованность их достижений в системе современного высшего образования. Подиёркивается, что вроссийском регионоведениинакоплен огромньй опьтп по разработке сиенариев и моделей взаимодействия России со странами Азии с учётом региональной специфики. Осуществляется исследование деятельности российского индолога, учёного, журналиста, просветителя и преподавателя А.В. Митрохина (19342002), лауреата премии Аж. Неру (1985 г.), более десяти лет работавшего в Индии и всю свою жизнь посвятивщего проблемам изучения регионов Южной и Центральной Азии. Проводится анализ основнысх коммуникативнысх практик А.В. Митрохина, результатьь которых нашли отражение $b$ его научнысх монографиях, научно-популярныс книгах $и$ статьях. Авторы приводят результаты проведённого ими лингвокультурологического исследования, подтверждаюоиие высокую эффрективность реализачии в 60-х - 70-х гг. ХX B. коммуникативньхх стратегий дружбы в рамках индо-советских отношений. На примере твориества А.В. Митрохина автори раскрыьвают иирокий спектр профессиональнььх компетенций советских индологов, обладавших глубокими знаниями о политической и соииокультурной структуре региона Южной Азии; о системнах взаимосвязях между отдельными сочиальными, экономическими и политическими институтами и группами; об этнопсихологических, этнокультурныс и религиозных особенностях межэтнического взаимодействия. В статье подиёркивается, что регионоведческие знания и навыки советских индологов позволяли эффективно прогнозировать развитие политической и экономической ситуачии в регионе Южной Азии и сопредельных регионах; развивать коммуникаиию; осуществлять экспертнную оценку по важным вопросам взаимодействия СССР со странами региона; разрабатыьвать эффрективныле коммуникативные стратегии и формировать позитивный образ своей странь на международной арене. Отмечается, ито изучение коммуникативного опыта советских индологов поможет современным студентам освоить методологию регионоведения; развить стратегическое мьпиление; расширить сферу учебно-научных интересов, а также знания об истории региона и межрегиональных взаимодействиях; изучить основы реализачии стратегий внещнего влияния и практику внешнеполитической пропаганды.

Ключевые слова: зарубежное регионоведение, коммуникативнье стратегии, российскоиндийские отношения, А.В. Митрохин, Южная Азия

Аля иитированил: Nesterova, O.A., Solodkova, O.L. Area Studies at the Modern University: Experience in Studying International Communication Strategies// Высшее образование в России. 2019. T. 28. № 11. C. 144-154.

DOI: https://doi.org/10.31992/0869-3617-2019-28-144-154

Статья поступила в редакиию 26.06.19

После доработки 28.08.19; 30.09.19

Принята к публикачии 04.10.19 